\begin{tabular}{c}
\hline Review of \\
ECONOMICS \\
and \\
INSTITUTIONS
\end{tabular}

\title{
Norm for Redistribution, Social Capital, and Perceived Tax Burden: Comparison between High- and Low-Income Households
}

\author{
Eiji Yamamura \\ Seinan Gakuin University
}

\begin{abstract}
This paper explores how a perceived tax burden is influenced by the degree that neighbors prefer income redistribution. Further, this paper investigates how the influence of neighbors is affected by the degree of interaction between neighbors. For these purposes, individual-level data and place of residence data were combined. After controlling for individual characteristics, I obtained the following key findings: people are more likely to perceive the amount of tax as low when neighbors are more likely to support redistribution policies. Further, this neighbor effect increases when community participation rates are high. This tendency is clearly observed in high-income groups but not in low-income groups. This implies that the norm for redistribution leads rich people to consider the tax burden as low. Further, the effect of the norm increases when there is a greater accumulation of social capital within a residential area.
\end{abstract}

JEL classification: D30; D63; H29; Z13

Keywords: Perceived tax; Norm; Redistribution; Social capital; Externality

Acknowledgement: The Japanese General Social Surveys (JGSS) are designed and carried out at: the Institute of Regional Studies at Osaka; University of Commerce in collaboration with the Institute of Social Science at the University of Tokyo under the direction of Ichiro TANIOKA, Michio NITTA, Noriko IWAI and Tokio YASUDA. The project is financially assisted by Gakujutsu Frontier Grant from the Japanese Ministry of Education, Culture, Sports, Science and Technology for 1999-2008 academic years, and the datasets are compiled and distributed by SSJ Data Archive, Center for Social Research and Data Archives, Institute of Social Science, the University of Tokyo.

Address: Department of Economics, Seinan Gakuin University, 6-2-92 Sawaraku Nishijin, Fukuoka 814-8511, Japan. (Phone: +81-92-823-4543. Fax: 81-92-823-2506 Email: yamaei@seinan-gu.ac.jp).

\section{Recommended Citation}

Yamamura, E. (2015). Norm for Redistribution, Social Capital, and Perceived Tax Burden: Comparison between High- and Low-Income Households. Review of Economics and Institutions, 6(2), Article 3. doi: 10.5202/rei.v6i2.184.

Retrieved from http://www.rei.unipg.it/rei/article/view/184 


\section{Introduction}

A critical issue for policy-makers is how to deter tax evasion. Income redistribution through tax collection increases the welfare of the poor, while decreasing that of the wealthy. In the case of progressive tax, the wealthy are more liable to pay tax that finances public spending. Inevitably, the wealthy have a greater incentive to evade tax than the poor, reducing public spending ${ }^{1}$ As a consequence, the size of the underground economy increases, resulting in a reduction of tax revenue. If tax evasion prevails, people consider it is unreasonable to pay tax. In this case, people perceive the tax burden to be too high to pay. However, assuming an interdependence of utility functions between rich and poor (Pauly, 1973), the wealthy have a motivation to pay tax. Poor people possibly commit a robbery and rich people are likely to be its victims. Such negative externality caused by poor is thought to influence the utility of rich people. In this case, interdependence of utility holds true even if people seek self-interest. The interdependence of utility functions is more common at the local level since closeness between rich and poor enhances interaction between them. For instance, within the same residential area, rich people are more likely to be interested in the circumstances of poorer people when the geographical and social distance between rich and poor people is small. Therefore, an individual's willingness to pay tax is, in part, influenced by social values such as social norms and relation with others.

The aim of this paper is to assess the effect of norms on the perceptions of rich people on tax and how the interactions between norms and social capital influence those perceptions. This paper attempts to compare the effect of the norm for redistribution on the tax burden between poor and rich groups using Japanese General Social Surveys (JGSS), which includes more than 10,000 observations. ${ }^{2}$

I found that people are more inclined to perceive tax as low in areas where residents are more likely to prefer redistribution policies. The effect of residents is greater when neighbors are actively involved in community activities. These tendencies were observed only for people from high-income groups and not for people in low-income groups. The cost and benefit from public goods is examined by looking at citizens: "a preference for public spending increases to be funded from additional taxes for which they were not liable. Consistently, there is evidence of greater demand for

${ }^{1}$ In contrast, indirect taxation such as consumption tax gives poor people the motivation to evade tax because their income is not high enough to pay such tax.

2 Tax base components include individual income and corporate income. Furthermore, the components of Japan's total revenue are almost equally distributed among individual income tax, corporate income tax, and indirect tax (Doi and Ihori, 2009, 135). In 2010, the rate of individual income tax income was 31.6\% in Japan, and $37.3 \%$ in Sweden (source: website of Ministry of Finance Japan accessed on August 29, 2014. http://www.mof.go.jp/taxpolicy/summary/condition/016.htm). 
public spending if this is financed out of taxes paid by others" (Gemmell et al. 2003, 811). Therefore, the poor, who are less likely to be liable for tax payments, support increases in public spending via tax burdens on the wealthy. From this we can derive an inference that rich people perceive a greater tax burden if they act in their own self-interest. In addition to self-interest, the role played by social values is considered to be a key factor in the realization of a welfare state and enhancing redistributive policy (e.g., Gordon, 1989; Luttmer, 2001; Klor and Shayo, 2010) 3reference for redistribution can be analyzed from the viewpoint of fairness (e.g., Galasso, 2003; Alesina and Angeletos, 2005; Tyran and Sausgruber, 2006; Rainer and Siedler, 2008; Luttens and Valfort, 2011). Altruism can give rich people an incentive to redistribute their wealth to poorer people (Fehr and Schmidt, 1999; Fong, 2001) ${ }^{4}$ This seems to reduce the perceived tax burden for rich people ${ }^{5}$ In this case, rich people do not perceive tax as high even when they are liable for progressive tax. Norms possibly lead people to behave altruistically even when they are actually selfish (Becker, 1996).6 A number of workplaces took into account the role of norms to analyze individuals' behavior concerning tax (e.g., Alm et al. 1999; Wenzel, 2004; 2005 a; 2005b; Balestrino, 2010; Cullis et al. 2012). It seems plausible that the norm for redistribution is formed within a community when community members prefer income redistribution. On the assumption that the psychological cost to deviate from 'proper behavior' or 'proper perception' is sufficiently high, the norm for redistribution leads rich people to perceive their tax burden as low even if individuals' act in their own self-interest.7 In addition to that norm, it has been recently found that people are likely to prefer redistribution policies in areas where social capital is sufficiently accumulated through frequent contact among neighbors (Yamamura, 2012). This suggests that an exter-

3 Trust, a key social value, is observed to be important when tax systems are considered. Generalized trust leads people to pay tax (Scholz and Lubell, 1998). Furthermore, trust in institutions such as government, the legal system, public officials and politics is thought to be important to establish tax morale and deter tax evasion (Scholz and Pinney, 1995; Torgler, 2003; Hammar et al. 2009), and such trust induces people to prefer the welfare state (Algan et al. 2012). Hence, the size of the welfare state is determined in part by social trust (Bergh and Bjørnskov, 2011).

4 Social values and social norms are associated with quality of institutions. For instance, trust is observed to determine the quality of institutions, which in turn affects GDP per capita (Bjørnskov and Méon, 2013). Thus, there is interplay between social norms and the enforcement of laws (Acemoglu and Jackson, 2014).

5 Social values are also important when the consequences of redistribution are considered. For instance, a redistributive policy's effectiveness seems to depend on religion (Chang, 2010) and culture (Luttmer and Singhal, 2011).

6 The interdependence of utility functions between the rich and poor possibly exists not only when rich people are benevolent but also when they are egoistic.

7 People who do not follow the norm are frowned upon and denounced by members who share the norm, reducing the level of utility. Even if there is not such a direct reaction, the violators are unlikely to enjoy any benefit (social support) from other members. Such negative externalities cause violators to incur psychological costs. 
nality via neighboring poor people increases social pressure on rich people, which leads rich people to prefer redistribution 8 However, the degree of such an externality and social pressure seems to depend on the norm. Assuming that neighbors do not prefer redistribution, rich people are unlikely to be an object of envy even if there are close interpersonal relations between neighbors. There is another possibility that neighbors' preferences for redistribution are less likely to result in a psychological cost for rich people if community members do not have contact with each other. If these hold true, the relation between the norm for redistribution and community participation is considered to be complementary. From this I infer that the effect of the norm regarding perceptions about tax seems to depend on social capital, which is regarded as the strength of personal networks within a community (Putnam, 2000). ${ }^{9}$ However, previous research ascertaining the determinants of perceptions about tax did not consider the effect of norms and social capital (Cuccia and Carnes, 2001; Gemmel et al. 2003, 2004; Feld and Larsen, 2012). The remainder of this paper is organized as follows. In Section 2 , the testable hypotheses are presented. Section 3 provides an explanation regarding data and the empirical method used. Section 4 presents the estimation results and their interpretation. The final section offers some conclusions.

\section{Hypotheses}

According to Becker (1996), norms are defined as "those common values of a group which influence an individual's behavior through being internalized as preferences" (Becker, 1996, 225). Norms play an important role in deterring opportunistic behavior such as tax evasion. ${ }^{10}$ The reason is that "if a person does not free-ride at the expense of others when that is advantageous to him, it may be because norms against the behavior lower the utility from the free-riding" (Becker, 1996, 225). Social interaction is defined in terms of a consumption externality or as the utility function of a person to include the reactions of others in his/her actions (Becker, 1974). Social interaction induces people to obey the norm. That is, "the enforcement of norms typically depends on negative reactions by peers toward individuals who

8 An individual's life satisfaction is influenced by the characteristics of their neighbors (Shields et al. 2008). Neighbors with higher education levels enhance university participation for middle class students, resulting in human capital accumulation (Foley, 2012).

9 Social capital influences not only individuals' perceptions but also their productivity. For instance, social capital and neighbors' characteristics are found to be key determinants regarding the earnings of microfinance borrowers (Gomez and Santor, 2001).

${ }^{10}$ Based on an analysis of questionnaire responses from Italy and the United Kingdom, Cullis et al. (2012) found that social norms frame the decision to pay tax. The degree of tax evasion depends on the probability that the tax evader will be caught and penalized. The perception of tax evasion, such as the ease to evade tax, possibly affects the perceived tax burden. 
deviate from 'proper' behavior" (Becker, 1996, 229) ${ }^{11}$ Take an example of punishment for violating a norm, those who act against the norm suffer social ostracism. That is, there is a psychological cost to violating a norm that defines 'proper behavior', ${ }^{12}$ The influence of a norm on individuals' utility differs according to the income group the individuals belong to (Becker, 1996). Income tax is progressive in Japan and so the rate of tax for rich people is higher than poor people. That is, for rich people, the benefit of public goods is more likely to be smaller than their tax burden. However, rich people can be sufficiently compensated for any reduction in utility when they pay tax because of the incorporation of the norm for redistribution in their preferences ${ }^{13}$ Therefore, even for rich people, a tax burden is considered relatively low when there is a norm that people should support redistribution. Accordingly, I advance

Hypothesis 1: The norm for redistribution leads rich people to perceive the tax burden as low. The effect of the norm seems to depend on the degree of so-

cial interaction. Further, the more people integrated into social relations, the greater the influence of the social interaction. This is because various benefits come from these relationships rather than market transactions. Once people are excluded from a strong relationship (such as interpersonal network formed in community), they lose the long-term benefit of the network (Hayami, 2001). Rich people therefore agree to obey the norm in return for a sufficiently large long-term benefit from the community network. Frequency of contact with neighbors is considered as a type of social capital (Putnam, 2000) and seems to reflect the degree of integration into the social relation. Hence, the cost to violate the norm is greater for residents in areas with a greater accumulation of social capital. In other words, peer 'pressure' lowers rich people's marginal disutility to absorb the norm and therefore to pay progressive tax. This leads me to propose

Hypothesis 2: The effect of the norm for redistribution on the perceptions of rich

${ }^{11}$ An experimental analysis found that the "minority of fair-minded players can force a big majority of selfish players to cooperate fully in the public goods game with punishment" (Fehr and Schmidt, 1999, 856).

${ }^{12}$ It is also important to take into account the proportion of transfer recipients in society when we analyze the degree of welfare society. The norm to deter tax evasion depends on the proportion of taxpayers and transfer recipients. As derived from a theoretical analysis, "a low-tax society supported by a majority of taxpayers or a high-tax society supported by a majority of transfer recipients... Given a low proportion of transfer recipients, the disutility of living on the work of others is high. On the other hand, a high proportion of transfer recipients will be associated with a low level of disutility" (Lindbeck et al. 1999, 30).

${ }^{13}$ It should be noted that the cost and benefit of paying tax for rich people depends on the taxation system. Basically, poor people are considered transfer recipients. However, the proportion of transfer recipients also varies according to the tax system. For instance, consumption tax is indirect and so poor people are also taxpayers. Poor people have an incentive to evade tax because their income is not enough to pay tax. 
people is greater when they live in an area where residents are more likely to interact with each other.

Perceived tax burden is linked to the benefit from public spending financed by taxes. According to the benefit principle of taxation, taxation may be applied on the basis of correspondence between the tax effort required and the benefit obtained by public goods and services. Hence, we postulate:

Hypothesis 3 If the benefit of public goods and services is sufficiently large, people perceive the tax burden as low even when the tax burden is high.

\section{Data and Methods}

\subsection{Data}

In this paper, I used JGSS data, which are individual-level data. 14 In JGSS surveys, a two-stage stratified sampling method is used. The surveys have been conducted in Japan since 2000. In this paper, the dataset covered 2000, 2001, 2002, 2003, 2005, 2006, and 2008 JGSS was designed as a Japanese counterpart to the General Social Survey (GSS) from the United States. To this end, JGSS asks standard questions regarding individuals' characteristics via face-to-face interviews. The data includes information about perceived income tax burden, opinions regarding income redistribution policies, marital and demographic (age and gender) status, annual household income, ${ }^{16}$ years of schooling, prefecture of residence, and prefecture of residence at 15 years old. A Japanese prefecture is the equivalent to a state in the United States or a province in Canada. There are 47 prefectures in Japan, and the average values for the variables included in the JGSS can be calculated for each prefecture. These average values reflect the characteristics of each prefecture. Data were collected from 22,796 adults, aged between 20 and 89 years. Respondents did not answer all of the survey questions; therefore, data regarding some variables are not available, and the number of samples used in the regression estimations is reduced to 7,794.

\footnotetext{
${ }^{14}$ Data for this secondary analysis, "Japanese General Social Surveys (JGSS), Ichiro Tanioka," was provided by the Social Science Japan Data Archive, Information Center for Social Science Research on Japan, Institute of Social Science, the University of Tokyo.

${ }^{15}$ Surveys were not conducted in 2004 and 2007. Surveys were conducted in 2009 and 2010 but the data is not available.

${ }^{16}$ In the original dataset, annual earnings were grouped into 19 categories, and it was assumed that everyone in each category earned the midpoint value. For the top category of "23 million yen and above," I assumed that everybody earned 23 million yen. Of the 7,794 observations used in the regression estimations, there were only 98 observations in this category. Therefore, the problem of top-coding should not be an issue here.
} 


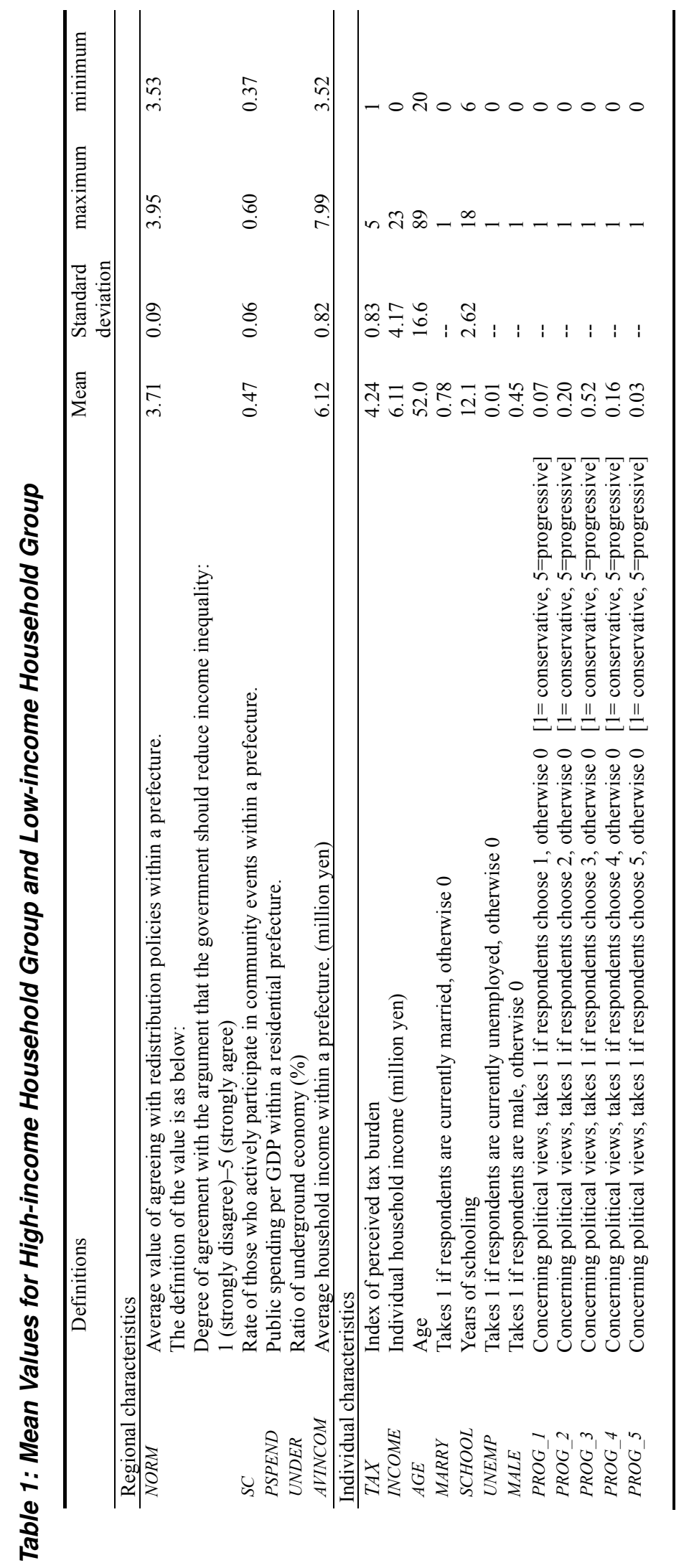

http://www.rei.unipg.it/rei/article/view/184 


\section{Figure 1: Distribution of Views Regarding Perceived Tax Burden}

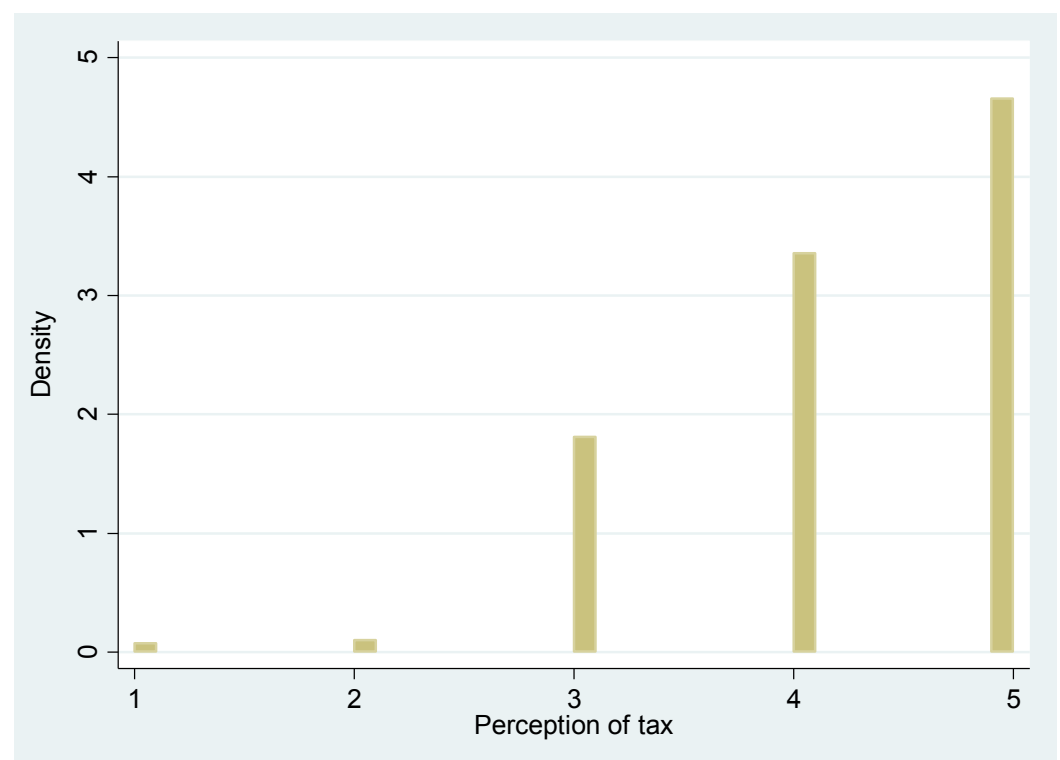

Note: Respondents were asked: "Do you think the amount of income tax you have to pay is high?". There were five response options: "1 (too low)", "2 (somewhat low)", "3 (about right)" "4 (somewhat high)", "5 (too high)". The number indicated in the figure is equivalent to the number of responses.

In comparison with international data, the use of JGSS data in this paper has the advantage that "within country analysis is much less likely to be subject to measurement error due to changes in institutional structures of redistributive policies" (Alesina and Giuliano, 2009, 22). The variables used in the regression estimations are shown in Table 1, which provides definitions, means, standard deviations, maximum values, and minimum values.

The distribution of TAX is shown in Figure 1; it shows that most people considered tax as "somewhat high" or "too high".

The key dependent variable is TAX (index of the perceived income tax burden). The JGSS asked the following question: "Do you think the amount of income tax you have to pay is high?" There were five response options: "1 (too low)", "2 (somewhat low)", "3 (about right)" "4 (somewhat high)", and " 5 (too high)". TAX is the response options chosen by the respondents.

The regional characteristics used in this paper are SC, NORM, and AVIN$C O M$. As stated in Table $1, S C$ is the average value of agreeing with redistribution policies within a prefecture. NORM is rate of those who actively participate in community events within a prefecture. PSPEND is the rate of public spending per GDP within an area. UNDER is the scale of the underground economy. AVINCOM is the average household income within a prefecture. The utility of people is considered to be influenced not only by one's own income but also by the income level of neighbors (e.g., Clark and Oswald, 1996; Neumark and Postlewaite, 1998; McBride, 2001; Stutzer, 2004). In other words, not only absolute income but also relative income is considered related to an individual's utility and, therefore, per- 
ceptions. This paper controls for both individual-level household income and average household income within residential prefectures to capture the relative income effect. For this purpose, in addition to respondents' household incomes, the income level of residential areas are taken into account. I used JGSS data to calculate the average household income within a prefecture (AVINCOM). With respect to individual characteristics, INCOME, AGE, MARRY, SCHOOL, UNEMP, MALE, PROG_2, PROG_3, PROG_4 and PROG 5 are used. Data for these variables can be obtained from the JGSS. The proxy for individuals' political ideology is constructed, based on responses to the JGSS question, "Where would you place your political views on a five-point scale?" There are five response options: "1 (conservative)" to "5 (progressive)". The placement of political views is captured by dummies: PROG 5 takes the value of 1 when the response is " 5 ", otherwise 0 . PROG_1, PROG_2, PROG_3, and PROG_4 are defined in a similar manner.

\subsection{Definitions of Social Norm and Social Capital}

Previous research has distinguished personal norms and social norms and scrutinized their effects when perceptions and attitudes regarding tax were analyzed (Wenzel, 2004; 2005a). However, in these studies social norms were measured in terms of individual perceptions regarding the social norm, based on the following questions: "Do MOST PEOPLE think they should honestly declare cash earnings on their tax return?" and "Do MOST PEOPLE think working for cash-in-hand payments without paying tax is a trivial offence?" (Wenzel, 2004, 220). This index is considered as a subjective evaluation rather than objective one. Hence, this measure of social norms is regarded as an endogenous variable. Endogeneity bias seems to occur when tax perception is a dependent variable and the measure of social norms is included as an independent variable. To avoid this problem, in this paper, the social norm is measured as the average rate of those who prefer redistribution policies within the area that the respondent resides. The JGSS included a question concerning preferences for redistribution: "It is the responsibility of the government to reduce the differences in income between families with high incomes and those with low incomes." There were five response options, ranging from " 1 (strongly disagree)" to " 5 (strongly agree)". In this paper, the average value of the responses within a residential prefecture is defined as the norm for redistribution shared by neighbors. In this research, and in line with Putnam (2000), the degree of participation in community activities is defined as social capital. ${ }^{17}$ The influence of neighbors is considered to be greater when people participate in community activities. That

${ }^{17}$ Social capital is defined as the features of a social organization such as networks and norms, as well as social trust facilitating coordination and cooperation (Putnam, 2000). Hence, social capital can be interpreted in various ways, thereby causing ambiguity and criticism regarding its measurement and definition (e.g., Paldam, 2000; Sobel, 2002; Durlauf 2002; Bjørnskov, 2006). 


\section{Figure 2: Distribution of Household Income}

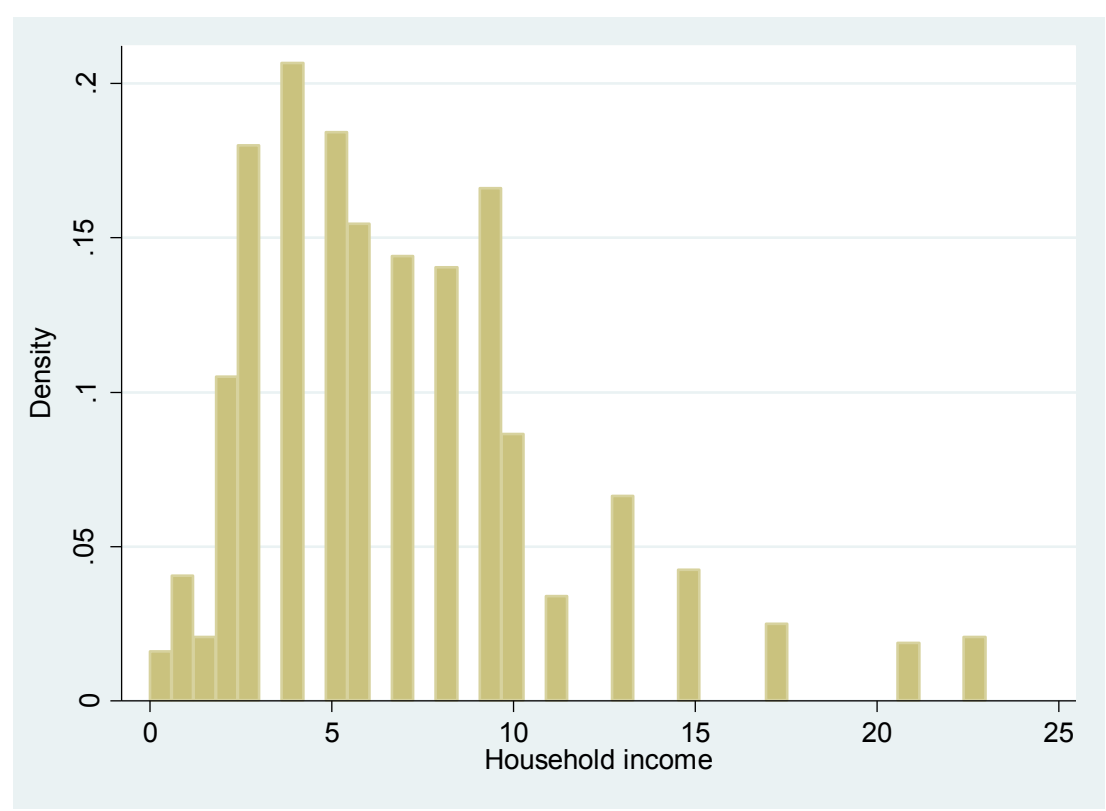

Note: One unit is equal to one million yen.

is, the effect of the norm on the perception of individuals is greater when they live in areas with higher levels of community involvement. In 1996, the Japan Broadcasting Corporation conducted a survey on the consciousness and behaviors of prefecture residents (Japan Broadcasting Corporation 1997). This survey included a question about the degree of community activity involvement: "Do you actively participate in community activities?" Respondents could choose one of three responses: "yes", "unsure", or "no". I calculated the rates for those who answered "yes" within a prefecture, and used this value as a measure of social capital. I also assumed that the rate of participation in community activities was stable over time. As mentioned earlier, there are 47 prefectures, and I obtained a proxy for each prefecture.

In this paper, as an objective category, high-income earners are defined as those with a household income higher than 6 million yen. The remainder of the residents are defined as low-income earners. However, as demonstrated in Figure 2, the shape of distribution of household income is not clearly divided at 6 million yen. Inevitably, this category is arbitrarily determined. To put it differently, those who belong to the 5 million yen group can also be considered as high-income earners although the category of this paper defined them as low-income earners. It is difficult to clearly divide respondents into two groups because "middle-income earners" can be considered to belong not only to the high-income group but also to the low-income group. To reduce any ambiguity regarding categorization, and following Derin-Güre and Uler (2010), an alternative category of income groups is suggested. The JGSS asked: "Compared with Japanese families in general, what would you say about your family income?" There were five response 


\section{Figure 3: Distribution of Subjective Income Position}

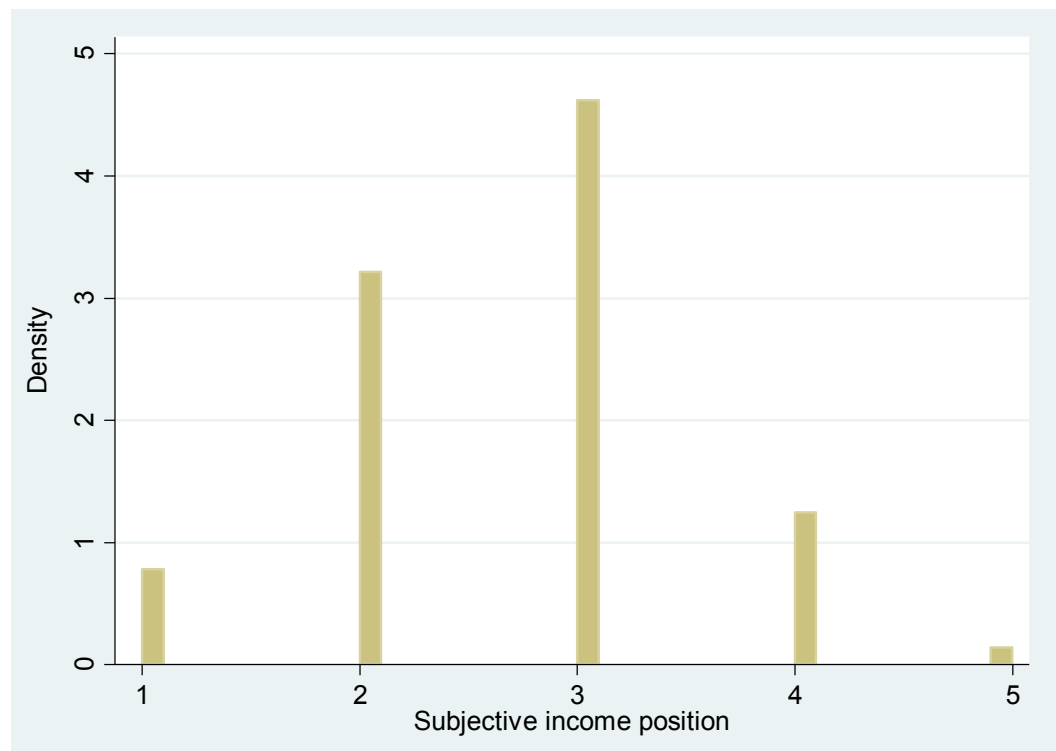

Note: Far below average (1), Below average (2), Average (3), Above average (4), and Far above average (5).

Table 2: Comparison of TAX, NORM, and SC between High-income Household Group and Low-income Household group

\begin{tabular}{llll}
\hline & High-income & Low-income & t-statistics \\
\hline TAX & 4.25 & 4.20 & $2.63 * * *$ \\
NORM & 3.69 & 3.71 & $14.2 * * *$ \\
SC & 0.46 & 0.47 & $10.7 * * *$ \\
& & & \\
\hline
\end{tabular}

Note: Respondents whose annual household income is higher than 6 million yen are classified as the high-income group. Respondents whose annual household income (or equivalent to) lower than 6 million yen are classified as the low-income group. All observations were used. Absolute values of t-statistics are the results of a mean difference test between high- and low-income household groups. ${ }^{* *}$ indicates significance at the $1 \%$ level.

options: "Far below average", "Below average", "Average", "Above average" and "Far above average".

Figure 3 demonstrates that the share of the "average" group is greatest and that there is now a clearer difference between high- and low-income groups than in Figure 2. In addition to the objective category, an alternative subjective category is made based on the responses to the question. In the subjective category, those who belong to the high-(low)income group are defined as those who considered themselves above (below) or far above (below) average income earners. In the alternative measure, those responded "average" are excluded from the sample.

Table 2 shows the comparison of key variables between high-income and low- income groups, which is based on the objective category. TAX for the high-income group is 0.05 points higher than that of the low-income group. 
Further, it is statistically different at the 1 percent level. This implies that, in comparison with people with low-income, people with high-income perceive income tax as higher. Values for NORM and SC for the high-income group are lower than the low-income group and statistically significant at the 1 percent level. This can be interpreted as stating that people belonging to the high-income group are less likely to live in areas where neighbors prefer income redistribution and actively participate in community events. The higher TAX is, the lower NORM and SC are. All in all, Table 2 suggests that NORM and SC are negative associated with TAX.

\subsection{Econometric Framework and Estimation Strategy}

In Figures 4(a), 4(b), and 4(c), the vertical axis shows the average TAX within a prefecture. The horizontal line shows NORM in each prefecture. Figure 4(a) shows the relationship between TAX and NORM, based on the whole sample. The relationship for the low-income group is demonstrated in Figure 4(b), while the relationship for the high-income group is shown in Figure 4(c). A cursory examination of Figure 4(a) shows that TAX is not obviously associated with NORM. For the low-income group, as in Figure 4(b), TAX is positively associated with NORM. In contrast, for the high-income group, as shown in Figure 4(c), TAX is negatively associated with NORM. This is consistent with Hypothesis 1. However, this relationship is observed when other factors are not controlled for. Hence, a more precise examination of the relationship is required via regression analysis using individual-level data matched with characteristics from residential areas. For the purpose of examining the hypotheses previously proposed, the estimated function of the baseline model takes the following form:

$$
\begin{aligned}
& T A X_{i m}=\alpha_{0}+\alpha_{1} N O R M_{m} * S C_{m}+\alpha_{2} N O R M_{m}+\alpha_{3} S C_{m}+\alpha_{4} P S P E N D_{m} \\
& +\alpha_{5} U N D E R_{m}+\alpha_{6} A V I N C O M_{m}+\alpha_{7} I N C O M_{i m}+\alpha_{8} A G E_{i m} \\
& +\alpha_{9} M_{A R R Y_{i m}}+\alpha_{10} S C H O O L_{i m}+\alpha_{11} U N E M P_{i m}+\alpha_{12} M A L E_{i m} \\
& +\alpha_{13} P R O G_{-} 2_{i m}+\alpha_{14} P R O G_{-} 3_{i m}+\alpha_{15} P R O G_{-} 4_{i m}+\alpha_{16} P R O G_{-} 5_{i m}+u_{i m}
\end{aligned}
$$

where $T A X_{i m}$ represents the dependent variable in individual $i$ and prefecture $m$. Regression parameters are represented by $\alpha$. As explained earlier, values for $T A X_{i m}$ range from 1 (too low) to 5 (too high). In this case, a multinomial response is an ordered response. Hence, the ordered probit model is appropriate to conduct the estimations (Greene 2008, 831-835). The error term is represented by $u_{i m}$. It is reasonable to assume that the observations may be spatially correlated within a prefecture, as the preference of one agent may well relate to the preference of another in the same prefecture. To consider such spatial correlation in line with this assumption, I calculated z-statistics using robust standard errors. The advantage of this approach is that the magnitude of the spatial correlation can be unique to each prefecture. In addition to spatial correlation, heteroscedasticity is thought to exist due to differences in individual income. To correct any 
Figure 4(a): Relationship between the Norm for Redistribution and Perceived Tax Burden for All Categories of Income Level

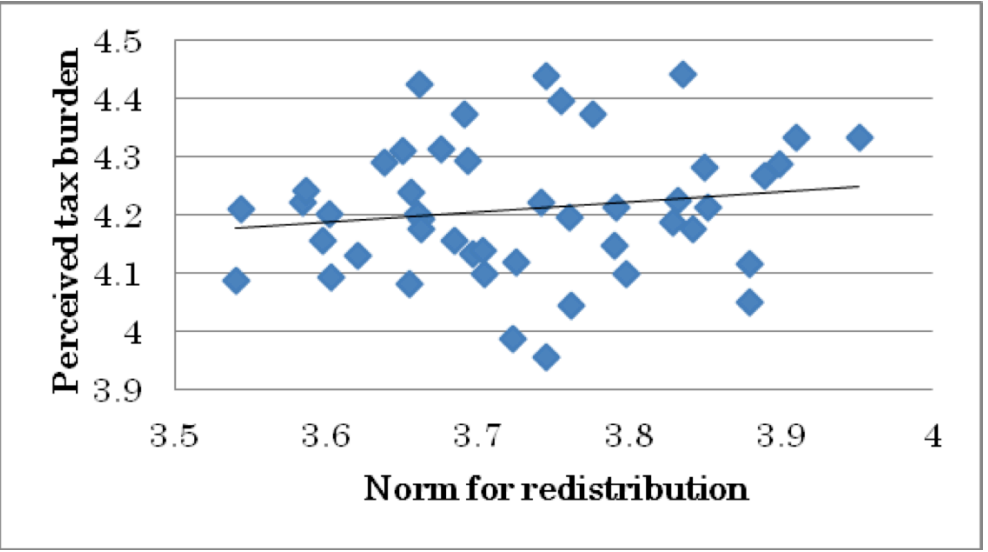

Figure 4(b): Relationship between the Norm for Redistribution and Perceived Tax Burden for Low-income Level Group (Annual Household Income is Lower than 6 Million Yen)

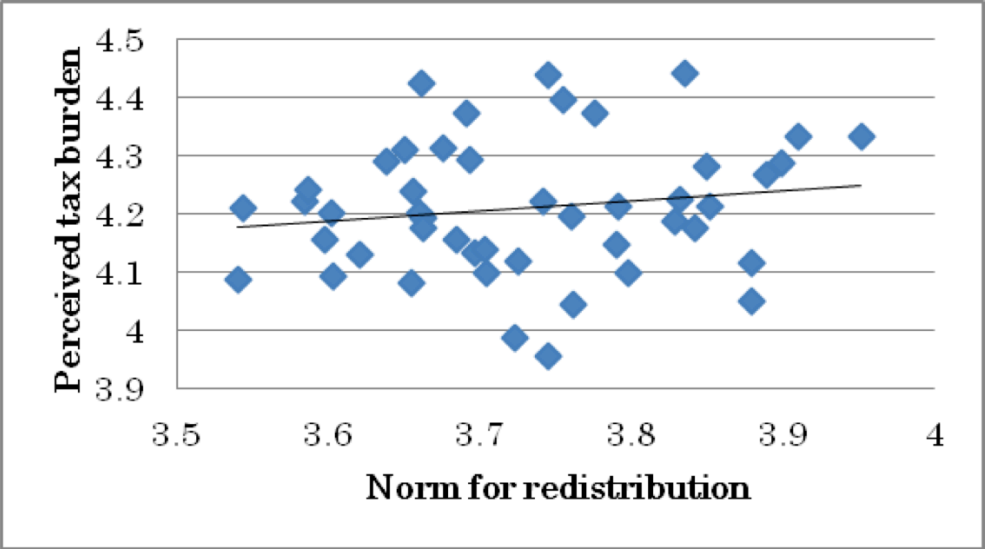

Figure 4(c): Relationship between the Norm for Redistribution and Perceived Tax Burden for High-income Level Group (Annual Household Income is Higher than 6 Million Yen)

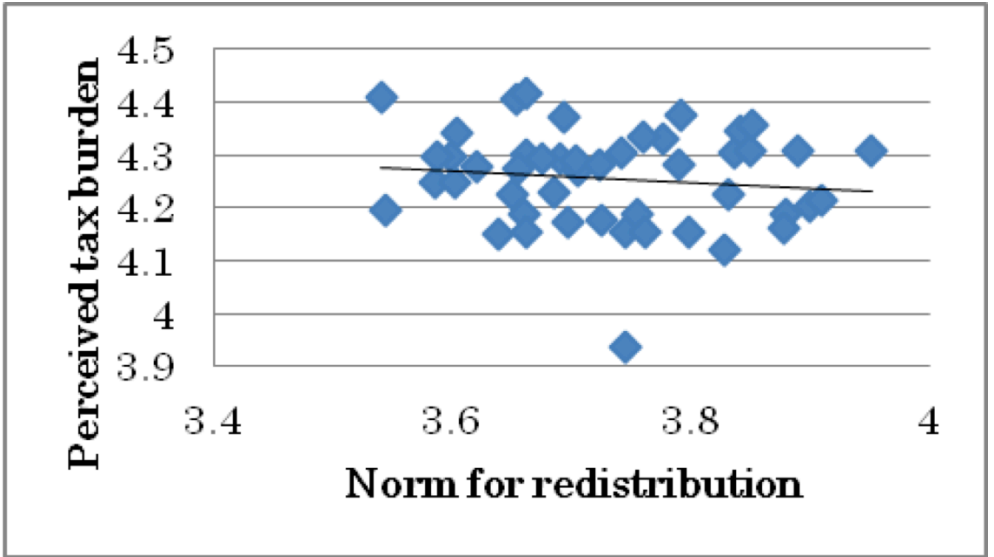


bias caused by heteroscedasticity, a multiplicative regression is used in this paper (Greene 2008, 169-172). Based on this model, individual income is used to control for heteroscedasticity; spatial correlation is also considered by robust standard errors clustered by prefecture. As explained earlier, in prior research, social norms have been measured looking at individuals' evaluations of social situations (Wenzel, 2004; 2005a). There seems to be reverse causality that individual's perceived tax burden influences his/her preference for redistribution policies. Therefore, endogeneity bias can occur. The rate of support for redistribution policies within a residential area can be considered as a macro-level variable. Hence, individual's perceived tax burden is unlikely to have a direct effect on residential area level support for redistribution policies. This is similar to the case that individual income level does not change GDP. Thus, NORM is thought to be exogenously determined. On this assumption, to alleviate this bias, the rate of those who support redistribution policies is used as a social norm in this paper ${ }^{18}$ From Hypothesis 1, NORM is anticipated to take the negative sign when a sample of rich people is used. Furthermore, it seems plausible that people who are content with life and economic conditions are more likely to have contact with their neighbors. If this holds true, those who are content and perceive tax as low are more inclined to have contact with neighbors. Hence, the causality between socialization and the perceived tax burden is ambiguous. To alleviate this bias, in this paper, I examine the effect of social capital formed in residential areas rather than an individual's socialization. From Hypothesis 2,NORM ${ }^{*} S C$ is predicted to take the negative sign. The scale of the underground economy in Japan has been estimated (Kadokura, 2002) as the ratio of products in Japan's underground economy to GDP (\%) ${ }^{19}$ This is available in each prefecture for 1998, which is before the first JGSS (Kadokura, 2002). Hence, in this paper, the ratio of products in Japan's underground economy in 1998 is used as a predetermined variable. UNDER is incorporated to capture the degree of tax evasion because tax evasion is positively associated with the scale of underground economy. If tax evasion is rampant, people consider the psychological cost of tax evasion to be low because they are less likely to be detected. Therefore, people perceive the tax burden as low. From Hypothesis 3, PSPEND is predicted to be negative because a high public spending rate indicates that the benefit obtained by public goods and services is sufficiently high. AVINCOM is included to control for relative income within a prefecture. As suggested by Luttmer (2005), increases in average income within a locality lead to reductions in residents' welfare. Accordingly, people feel unhappier when the average income increases. People are thought to perceive tax as high.

\footnotetext{
${ }^{18}$ Even if effect of individual level perceived tax burden on the area level preference for redistribution is not sizable, a little effect seems to exist. It should be noted that the possibility of endogenous bias.

19 This is fitted values estimated by using available social and economic variables.
} 
In this paper, for poor people, $A V I N C O M$ is expected to take the positive sign. However, an increase in AVINCOM appears to lead people to expect that they can earn more. If this is so, the sign for AVINCOM becomes negative. Following previous research concerning redistribution (e.g., Ravallian and Lokshin, 2000; Corneo and Grüner, 2002; Ohtake and Tomioka, 2004; Alesina and La Ferrara, 2005; Rainer and Seidler, 2008; Alesina and Giuliano, 2009; Yamamura, 2012), INCOME, AGE, MARRY, SCHOOL, UNEMP and $M A L E$ are incorporated as independent variables to control for individual characteristics. Political ideology plausibly influences preferences for redistribution. It is important to control for this ideology when preferences for income redistribution are estimated (Bernasconi, 2006; Alesina and Giuliano, 2009). Hence, perceptions about tax burdens seem to be influenced by political ideology. This is captured by PROG_2 -PROG_5 with PROG_1 (conservative view), as reference groups.

\section{Estimation Results}

Tables 3(a), (b), 4(a), and (b) present the estimation results of the ordered probit model. All control variables reported in Tables 3(a) and (b) are also included in Tables 4(a) and (b). However, the results of the control variables are not reported in Tables 4(a) and (b) because their results are similar to those in Tables 3(a) and (b). The results of the baseline model, which does not include the interaction term between NORM and SC, are reported in Tables 3(a) and (b). Tables 4(a) and (b) show the results when the interaction term between NORM and SC is included. In each table, the estimation results, based on a sample containing rich and poor respondents, are shown in columns (1) and (4) of Tables 3(a) and 4(a). For the purpose of comparing factors determining TAX between high-income and low-income groups, the sample is divided into high-income and low-income groups. The results for the high-income group are presented in columns (2) and (5) of Tables 3(a) and 4(a) and in columns (1) and (3) of Tables 3(b) and 4(b). The results for the low-income group are presented in columns (3) and (6) of Tables 3(a) and 4(a) and in columns (2) and (4) of Tables 3(b) and 4(b). As pointed out by Luttmer (2005), there is "the possibility that cross-section results are driven by selection of people who are happier by nature into areas that are relatively poorâOne might worry that movers may have had something unobserved happen to them" (Luttmer, 2005, 977). This unobserved factor can cause estimation bias. The JGSS provided data regarding not only current residential prefectures but also the residential prefectures of respondents at 15 years of age. If the current residential prefecture is not the same as the prefecture at 15 years old, respondents are considered to be "movers". To alleviate this bias, following Luttmer (2005) and Yamamura (2012), I conducted estimations by excluding all respondents who had moved to a different prefecture. Results using the ordered probit estimation are exhibited in 
columns (1)â(3) of Tables 3(a) and 4(a), and in columns (1) and (2) in Tables $3(\mathrm{~b})$ and 4(b). For a robustness check, estimation results based on multiplicative regressions are exhibited in columns (4)â(6) of Tables 3(a) and 4(a), and in columns (3) and (4) in Tables 3(b) and 4(b). I see from Table 3(a) that the signs for NORM have the expected negative sign for results based on the whole sample and the high-income group sample. Furthermore, as presented in columns (2) and (5), it is statistically significant at the 1 percent level for high-income group. In contrast, in columns (3) and (6), the sign of NORM is positive although not statistically significant for the lowincome group. The coefficients exhibited in Table 3(a) cannot be interpreted as marginal effects and it is difficult to interpret them in the ordered probit model. Hence, to determine economic significance, I see a marginal effect of NORM. The values for TAX range between 1 and 5 and so the marginal effect of NORM varies according to values of TAX (Greene, 2008, 831-835) ${ }^{20}$ In the third line from bottom, Tables 3(a) show the marginal effect of NORM on the probability that the value of TAX is 5 (perceive tax burden as being "too high").

In columns (2), the absolute values of the marginal effect of NORM are 0.37 , respectively. Further, they are statistically significant at the 1 percent level. This can be interpreted as a 1 percent increase in those who support redistribution policies within a residential area leads to a 0.37 percent decrease in the probability that high-income people perceive their tax burden as "too high". 21 These results are in line with Hypothesis 1. In Table 3(a), PSPEND is negative and statistically significant in columns (1), (2), (4), and (5). This is consistent with Hypothesis 3. In contrast, UNDER is negative as expected but is not statistically significant. Concerning AVINCOM, the higher their neighbors' income, the less satisfied people become. If their neighbors have high levels of income, then people perceive tax as high. In contrast, poor people expect that they can earn more if their neighbors have higher levels of income. Hence, people perceive the tax as low. The former effect is neutralized by the latter, and so AVINCOM is not statistically significant for whole sample and the low-income group sample. For the high-income group, AVINCOM has the negative sign and is statistically significant at the 1 percent level. The reason seems to be that the latter effect is distinctly greater than the former. As for individual characteristics reported in Table 3(a), the sign for INCOME is positive for whole sample and the high-income group sample, whereas it is negative for the low-income group sample. With the exception of column (3), it is statistically significant.

20 The marginal effects of NORM can be calculated for each value of TAX; that is, the marginal effect of NORM on the probability that TAX is 5, the marginal effect of NORM on the probability that TAX is 4, the marginal effect of NORM on the probability that TAX is 3, the marginal effect of NORM on the probability that TAX is 2 , and the marginal effect of NORM on the probability that TAX is 1 .

${ }^{21}$ There is possibility that endogenous bias exists. Hence, it should be noted that the marginal effect of NORM suffered from the bias. 
Table 3(a): Baseline Model: Dependent Variable is TAX: Each Group is Categorized Based on an Objective Measure (Annual Household Income)

\begin{tabular}{|c|c|c|c|c|c|c|}
\hline & & \multicolumn{2}{|c|}{ Ordered probit } & \multicolumn{3}{|c|}{ Multiplicative model } \\
\hline & (1) & (2) & (3) & (4) & (5) & $(6)$ \\
\hline & All & $\begin{array}{l}\text { High- } \\
\text { income }\end{array}$ & $\begin{array}{l}\text { Low- } \\
\text { income }\end{array}$ & All & $\begin{array}{l}\text { High- } \\
\text { income }\end{array}$ & $\begin{array}{l}\text { Low- } \\
\text { income }\end{array}$ \\
\hline \multicolumn{7}{|c|}{ Regional characteristics } \\
\hline NORM & $\begin{array}{l}-0.30 \\
(-1.46)\end{array}$ & $\begin{array}{l}-0.96 * * * \\
(-3.20)\end{array}$ & $\begin{array}{l}0.20 \\
(0.78)\end{array}$ & $\begin{array}{l}-0.24 \\
(-1.59)\end{array}$ & $\begin{array}{l}-0.75^{* * *} \\
(-3.24)\end{array}$ & $\begin{array}{l}0.16 \\
(0.84)\end{array}$ \\
\hline PSPEND & $\begin{array}{l}-0.01 * * \\
(-2.35)\end{array}$ & $\begin{array}{l}-0.01 * * \\
(-2.16)\end{array}$ & $\begin{array}{l}-0.01 \\
(-1.09)\end{array}$ & $\begin{array}{l}-0.01 * * \\
(-2.40)\end{array}$ & $\begin{array}{l}-0.01 * * \\
(-2.21)\end{array}$ & $\begin{array}{l}-0.01 \\
(-1.11)\end{array}$ \\
\hline UNDER & $\begin{array}{l}-0.01 \\
(-0.51)\end{array}$ & $\begin{array}{l}-0.01 \\
(-0.31)\end{array}$ & $\begin{array}{l}-0.03 \\
(-0.68)\end{array}$ & $\begin{array}{l}-0.01 \\
(-0.51)\end{array}$ & $\begin{array}{l}-0.01 \\
(-0.45)\end{array}$ & $\begin{array}{l}-0.02 \\
(-0.82)\end{array}$ \\
\hline AVINCOM & $\begin{array}{l}-0.06^{* * * *} \\
(-2.73)\end{array}$ & $\begin{array}{l}-0.14 * * * \\
(-4.66)\end{array}$ & $\begin{array}{l}0.01 \\
(0.53)\end{array}$ & $\begin{array}{l}-0.05 * * * \\
(-2.94)\end{array}$ & $\begin{array}{l}-0.11 * * * \\
(-4.43)\end{array}$ & $\begin{array}{l}0.01 \\
(0.46)\end{array}$ \\
\hline \multicolumn{7}{|c|}{ Individual characteristics } \\
\hline INCOME & $\begin{array}{l}0.01 * \\
(1.70)\end{array}$ & $\begin{array}{l}0.01 * * * \\
(3.34)\end{array}$ & $\begin{array}{l}-0.02 * \\
(-1.68)\end{array}$ & $\begin{array}{l}0.01 * * \\
(2.10)\end{array}$ & $\begin{array}{l}0.01 * * * \\
(3.39)\end{array}$ & $\begin{array}{l}-0.01 \\
(-0.81)\end{array}$ \\
\hline$A G E$ & $\begin{array}{l}-0.003 * * \\
(-2.55)\end{array}$ & $\begin{array}{l}0.0003 \\
(0.17)\end{array}$ & $\begin{array}{l}-0.006 * * * \\
(-4.07)\end{array}$ & $\begin{array}{l}-0.002 * * \\
(-2.57)\end{array}$ & $\begin{array}{l}0.0003 \\
(0.17)\end{array}$ & $\begin{array}{l}-0.004 * * * \\
(-4.07)\end{array}$ \\
\hline MARRY & $\begin{array}{l}0.06^{*} \\
(1.93)\end{array}$ & $\begin{array}{l}0.08 \\
(1.27)\end{array}$ & $\begin{array}{l}0.07 * \\
(1.87)\end{array}$ & $\begin{array}{l}0.05 * * \\
(1.97)\end{array}$ & $\begin{array}{l}0.05 \\
(1.26)\end{array}$ & $\begin{array}{l}0.04 \\
(1.42)\end{array}$ \\
\hline SCHOOL & $\begin{array}{l}-0.02 * * * \\
(-2.93)\end{array}$ & $\begin{array}{l}-0.005 \\
(-0.62)\end{array}$ & $\begin{array}{l}-0.02 * * * \\
(-2.58)\end{array}$ & $\begin{array}{l}-0.01 * * \\
(-2.56)\end{array}$ & $\begin{array}{l}-0.002 \\
(-0.30)\end{array}$ & $\begin{array}{l}-0.02 * * \\
(-2.51)\end{array}$ \\
\hline UNEMP & $\begin{array}{l}0.03 \\
(0.30)\end{array}$ & $\begin{array}{l}-0.22 \\
(-0.96)\end{array}$ & $\begin{array}{l}0.11 \\
(0.89)\end{array}$ & $\begin{array}{l}0.02 \\
(0.23)\end{array}$ & $\begin{array}{l}-0.18 \\
(-0.92)\end{array}$ & $\begin{array}{l}0.09 \\
(1.04)\end{array}$ \\
\hline MALE & $\begin{array}{l}0.01 \\
(0.33)\end{array}$ & $\begin{array}{l}-0.03 \\
(-0.78)\end{array}$ & $\begin{array}{l}0.04 \\
(1.05)\end{array}$ & $\begin{array}{l}0.004 \\
(0.16)\end{array}$ & $\begin{array}{l}-0.03 \\
(-0.89)\end{array}$ & $\begin{array}{l}0.02 \\
(0.84)\end{array}$ \\
\hline PROG_2 & $\begin{array}{l}-0.01 \\
(-0.10)\end{array}$ & $\begin{array}{l}-0.01 \\
(-0.09)\end{array}$ & $\begin{array}{l}0.01 \\
(0.10)\end{array}$ & $\begin{array}{l}0.01 \\
(0.14)\end{array}$ & $\begin{array}{l}-0.01 \\
(-0.09)\end{array}$ & $\begin{array}{l}0.02 \\
(0.42)\end{array}$ \\
\hline PROG_3 & $\begin{array}{l}0.20 * * * \\
(3.72)\end{array}$ & $\begin{array}{l}0.19 * * \\
(2.16)\end{array}$ & $\begin{array}{l}0.22 * * * \\
(3.33)\end{array}$ & $\begin{array}{l}0.17 * * * \\
(3.88)\end{array}$ & $\begin{array}{l}0.14 * * \\
(2.24)\end{array}$ & $\begin{array}{l}0.19 * * * \\
(3.74)\end{array}$ \\
\hline PROG_4 & $\begin{array}{l}0.18 * * * \\
(2.67)\end{array}$ & $\begin{array}{l}0.17^{*} \\
(1.88)\end{array}$ & $\begin{array}{l}0.19 * * \\
(2.25)\end{array}$ & $\begin{array}{l}0.14 * * * \\
(2.73)\end{array}$ & $\begin{array}{l}0.12 * \\
(1.84)\end{array}$ & $\begin{array}{l}0.17 * * \\
(2.64)\end{array}$ \\
\hline PROG_5 & $\begin{array}{l}0.52 * * * \\
(4.88)\end{array}$ & $\begin{array}{l}0.74 * * * \\
(4.12)\end{array}$ & $\begin{array}{l}0.39 * * * \\
(3.16)\end{array}$ & $\begin{array}{l}0.35 * * * \\
4.95)\end{array}$ & $\begin{array}{l}0.44 * * * \\
(4.33)\end{array}$ & $\begin{array}{l}0.28 * * * \\
(3.28)\end{array}$ \\
\hline $\begin{array}{l}\text { Marginal effect } \\
\text { NORM }\end{array}$ & $\begin{array}{l}-0.11 \\
(-1.46)\end{array}$ & $\begin{array}{l}-0.37 * * * \\
(-3.21)\end{array}$ & $\begin{array}{l}0.08 \\
(0.78)\end{array}$ & & & \\
\hline Log likelihood & -6283 & -2730 & -3526 & -6967 & 2994 & -3948 \\
\hline Observations & 5606 & 2479 & 3127 & 5606 & 2479 & 3127 \\
\hline
\end{tabular}

Note: Respondents whose annual household income is higher than 6 million yen are classified as the high-income group. Respondents whose annual household income is lower than (or equivalent to) 6 million yen are classified as the low-income group. Values in each variable are coefficients. Sample is limited to people living in the same prefecture they lived in at 15 years of age. In the third line from the bottom, the marginal effect of NORM on the probability that TAX is 5 is reported. Numbers in parentheses are z-statistics calculated using robust standard errors clustered in the prefecture. ${ }^{*},{ }^{* *}$, and ${ }^{* *}$ indicate significance at the $10 \%, 5 \%$, and $1 \%$ levels, respectively. In all estimations, year dummies are included as independent variables but are not reported because of space limitations. 
Table 3(b): Dependent Variable is TAX: Each Group is Categorized Based on a Subjective Measure

\begin{tabular}{|c|c|c|c|c|}
\hline & \multicolumn{2}{|c|}{ Ordered probit } & \multicolumn{2}{|c|}{ Multiplicative model } \\
\hline & $\begin{array}{c}(1) \\
\text { High-income }\end{array}$ & $\begin{array}{c}(2) \\
\text { Low-income }\end{array}$ & $\begin{array}{c}(3) \\
\text { High-income }\end{array}$ & $\begin{array}{c}(4) \\
\text { Low-income }\end{array}$ \\
\hline \multicolumn{5}{|l|}{$\begin{array}{l}\text { Regional } \\
\text { characteristics }\end{array}$} \\
\hline NORM & $\begin{array}{l}-1.25 * * * \\
(-2.74)\end{array}$ & $\begin{array}{l}0.16 \\
(0.70)\end{array}$ & $\begin{array}{l}-0.88 * * * \\
(-2.72)\end{array}$ & $\begin{array}{l}0.16 \\
(0.84)\end{array}$ \\
\hline PSPEND & $\begin{array}{l}-0.01 \\
(-0.90)\end{array}$ & $\begin{array}{l}-0.004 \\
(-0.78)\end{array}$ & $\begin{array}{l}-0.01 \\
(-0.99)\end{array}$ & $\begin{array}{l}-0.003 \\
(-0.66)\end{array}$ \\
\hline UNDER & $\begin{array}{l}-0.11 \\
(-1.46)\end{array}$ & $\begin{array}{l}0.01 \\
(0.57)\end{array}$ & $\begin{array}{l}-0.08 \\
(-1.36)\end{array}$ & $\begin{array}{l}0.02 \\
(0.90)\end{array}$ \\
\hline AVINCOM & $\begin{array}{l}-0.15 * * \\
(-2.29)\end{array}$ & $\begin{array}{l}-0.02 \\
(-0.64)\end{array}$ & $\begin{array}{l}-0.11 * * \\
(-2.35)\end{array}$ & $\begin{array}{l}-0.02 \\
(-0.67)\end{array}$ \\
\hline \multicolumn{5}{|l|}{$\begin{array}{l}\text { Individual } \\
\text { characteristics }\end{array}$} \\
\hline INCOME & $\begin{array}{l}0.02 * * \\
(2.52)\end{array}$ & $\begin{array}{l}-0.01 \\
(-0.96)\end{array}$ & $\begin{array}{l}0.02 * * \\
(2.50)\end{array}$ & $\begin{array}{l}-0.01 \\
(-0.97)\end{array}$ \\
\hline$A G E$ & $\begin{array}{l}-0.001 \\
(-0.23)\end{array}$ & $\begin{array}{l}-0.002 \\
(-1.29)\end{array}$ & $\begin{array}{l}-0.001 \\
(-0.28)\end{array}$ & $\begin{array}{l}-0.002 \\
(-1.56)\end{array}$ \\
\hline$M A R R Y$ & $\begin{array}{l}0.02 \\
(0.23)\end{array}$ & $\begin{array}{l}0.16 * * * \\
(3.13)\end{array}$ & $\begin{array}{l}0.01 \\
(0.22)\end{array}$ & $\begin{array}{l}0.13 * * * \\
(3.06)\end{array}$ \\
\hline SCHOOL & $\begin{array}{l}-0.01 \\
(-0.28)\end{array}$ & $\begin{array}{l}-0.01 \\
(-1.27)\end{array}$ & $\begin{array}{l}-0.004 * * \\
(-0.32)\end{array}$ & $\begin{array}{l}-0.01 \\
(-1.17)\end{array}$ \\
\hline$U N E M P$ & $\begin{array}{l}-0.08 \\
(-0.12)\end{array}$ & $\begin{array}{l}0.19 \\
(1.21)\end{array}$ & $\begin{array}{l}-0.13 \\
(-0.24)\end{array}$ & $\begin{array}{l}0.13 \\
(1.27)\end{array}$ \\
\hline$M A L E$ & $\begin{array}{l}0.05 \\
(0.61)\end{array}$ & $\begin{array}{l}-0.01 \\
(-0.14)\end{array}$ & $\begin{array}{l}0.02 \\
(0.45)\end{array}$ & $\begin{array}{l}-0.01 \\
(-0.19)\end{array}$ \\
\hline PROG_2 & $\begin{array}{l}-0.03 \\
(-0.24)\end{array}$ & $\begin{array}{l}0.08 \\
(0.85)\end{array}$ & $\begin{array}{l}-0.01 \\
(-0.08)\end{array}$ & $\begin{array}{l}0.09 \\
(1.09)\end{array}$ \\
\hline$P R O G \_3$ & $\begin{array}{l}0.17 \\
(1.27)\end{array}$ & $\begin{array}{l}0.31 * * * \\
(3.62)\end{array}$ & $\begin{array}{l}0.14 \\
(1.48)\end{array}$ & $\begin{array}{l}0.27 * * * \\
(3.74)\end{array}$ \\
\hline$P R O G \_4$ & $\begin{array}{l}0.20 \\
(1.37)\end{array}$ & $\begin{array}{l}0.21 * * \\
(2.31)\end{array}$ & $\begin{array}{l}0.14 \\
(1.41)\end{array}$ & $\begin{array}{l}0.18 * * \\
(2.31)\end{array}$ \\
\hline PROG_5 & $\begin{array}{l}0.25 \\
(0.98)\end{array}$ & $\begin{array}{l}0.56 * * * \\
(4.03)\end{array}$ & $\begin{array}{l}0.16 \\
(1.00)\end{array}$ & $\begin{array}{l}0.40 * * * \\
(4.05)\end{array}$ \\
\hline $\begin{array}{l}\text { Marginal effect } \\
\text { NORM }\end{array}$ & $\begin{array}{l}-0.48 * * * \\
(-2.74)\end{array}$ & $\begin{array}{l}0.06 \\
(0.70)\end{array}$ & & \\
\hline Log likelihood & -852 & -2559 & -931 & -2956 \\
\hline Observations & 784 & 2280 & 784 & 2280 \\
\hline
\end{tabular}

Note: Respondents who considered themselves above or far above average income earners are classified as the high-income group. Respondents who considered themselves below or far below average income earners are classified as the low-income group. Respondents who considered themselves as average earners are included in the estimations in columns (1) and (4) in Table 3(a), but excluded from the sample in Table 3(b). Values in each variable are coefficients. Sample is limited to people living in the same prefecture they lived in at 15 years of age. In the third line from the bottom, the marginal effect of NORM on the probability that TAX is 5 is reported. Numbers in parentheses are z-statistics calculated using robust standard errors clustered in the prefecture. * ${ }^{* *}$, and ${ }^{* * *}$ indicate significance at the $10 \%, 5 \%$, and $1 \%$ levels, respectively. In all estimations, year dummies are included as independent variables but are not reported because of space limitations. 
This is consistent with the assumption that high-income people are more inclined to perceive the tax burden as high as income tax is progressive. A significant negative sign for $S C H O O L$ is observed in all estimations. It is statistically significant for whole sample and the low-income group sample. People with higher education are more likely to expect higher future earnings even if they are currently poor. The income tax burden for the low-income group is smaller than the high-income group when income tax is progressive. Hence, the results for $S C H O O L$ can be interpreted as suggesting that there is high probability that higher educated poor people will become rich in the future, and therefore poor people will perceive the tax burden as low. PROG3, PROG4 and PROG5 have the positive sign and are statistically significant in all estimations. In my interpretation, these results imply that more liberal people are less likely to trust the government and so feel that tax is not effectively used. As a consequence, the tax burden is perceived to be higher than the benefit from tax, leading liberal people to perceive tax as high. However, the assumption that liberal people are less likely to the trust government is open to discussion. A closer examination of this assumption is beyond the scope of this paper and so should be explored in future research. Regarding NORM, the results reported in Table 3(b) are similar to those in Table 3(a). This leads me argue that those who consider themselves as high-income earners are more likely to perceive their tax as low if neighbors are more likely to prefer redistribution when the alternative subjective category regarding high-income people is used. Therefore, Hypothesis 1 is strongly supported. In contrast, PSPEND continues to be negative but is not statistically significant. Therefore, Hypothesis 3 is not supported.

Turning now to Table 4 (a), I focus on $\operatorname{NORM}^{*} S C$, which is the key variable to test Hypothesis 2 because the results of the other control variables are similar to those exhibited in Table 3(a). As exhibited in columns (1), (2), (4) and (5), NORM*SC yields the negative sign for all samples and the high-income sample. Further, for the high-income sample, it is statistically significant. In contrast, NORM ${ }^{*} S C$ produces the positive sign for the lowincome sample although it is not statistically significant. That is, the effect of NORM becomes greater when there is a greater accumulation of social capital within a residential area through participation in community activities. The results of Table $4(\mathrm{~b})$, based on an alternative category regarding high- and low-income groups, are almost identical to those of Table 4(a). Considering Tables 4(a) and (b) together leads me to assert that the effect of NORM for rich people is strengthen by SC and so Hypothesis 2 is strongly supported. To sum the various estimated results presented thus far, I conclude, as a whole, that the estimation results examined in this section are consistent with Hypotheses 1 and 2, and hence support them reasonably well. The above findings imply that the norm for redistribution within a residential area leads rich people to agree with higher tax rates even if in- 
Table 4(a): Model Including Cross Term between NORM and SC: Dependent Variable is TAX, each Group is Categorized Based on Objective Measure (Annual Household Income)

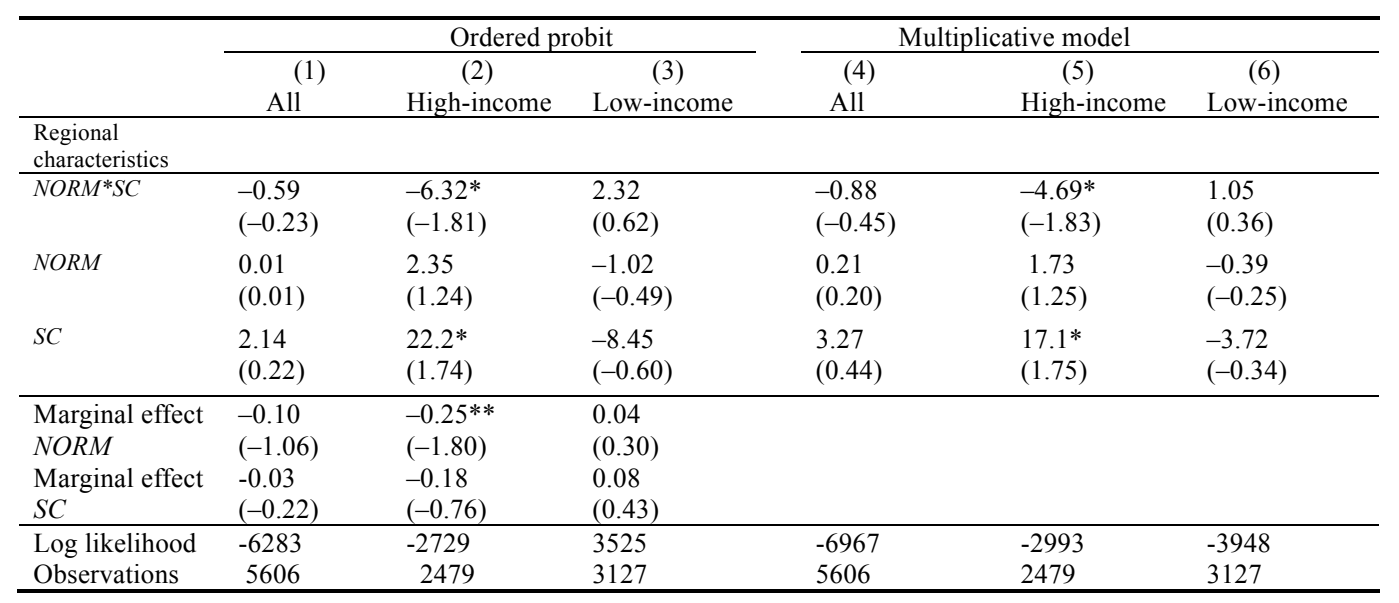

Note: Respondents whose annual household income is higher than 6 million yen are classified as the high-income group. Respondents whose annual household income is lower than (or equivalent to) 6 million yen are classified as the low-income group. Values are coefficients in each variable. Sample is limited to people living in the same prefecture they lived in at 15 years of age. In the third line from the bottom, the marginal effects of NORM and $S C$ on the probability that TAX is 5 are reported. Numbers in parentheses are z-statistics calculated using robust standard errors clustered in the prefecture. * , ${ }^{* *}$, and ${ }^{* * *}$ indicate significance at the $10 \%, 5 \%$, and $1 \%$ levels, respectively. In all estimations, control variables used in Table 3(b) are included in the model but the results are not reported because of space limitations.

come tax is progressive. Further, that effect of the norm is strengthened by social capital formed by neighbors. According to the vicious-cycle hypothesis, countries with greater income inequality demonstrate less support for redistribution and greater acceptance of wage inequality than their more equal counterparts (Alesina et al., 2001). For example, social capital has declined in the United States (Putnam, 2000). This might be one reason why the "vicious cycle" is observed in the United States. To the contrary, recent research by Kerr (2014) found that a growth in inequality is met with greater concern over inequality, greater support for government-led redistribution to the poor, and greater support for more progressive taxation. This is congruent with findings from the United States, where rich people are more likely to increase charitable contributions for inequality reduction than poor people (Derin-Güre and Uler, 2010). Thus, based on Kerr (2014), a mechanism appears to exist where growth in inequality forms the norm to prefer redistribution, which in turn causes people to perceive tax as being low. It would be worthwhile to empirically explore whether the mechanism does indeed exist.

\section{Conclusions}

Income tax in Japan is progressive: the higher the income, the greater the tax. That is, the net benefit from tax is smaller for the wealthy than the 
Table 4(b): Model Including Cross Term between NORM and SC. Dependent Variable is TAX: Each Group is Categorized Based on Subjective Measure

\begin{tabular}{|c|c|c|c|c|}
\hline & \multicolumn{2}{|c|}{ Ordered probit } & \multicolumn{2}{|c|}{ Multiplicative model } \\
\hline & $\begin{array}{c}\text { (1) } \\
\text { High-income }\end{array}$ & $\begin{array}{c}(2) \\
\text { Low-income }\end{array}$ & $\begin{array}{c}\text { (3) } \\
\text { High-income }\end{array}$ & $\begin{array}{c}(4) \\
\text { Low-income }\end{array}$ \\
\hline $\begin{array}{l}\text { Regional } \\
\text { characteristics }\end{array}$ & & & & \\
\hline NORM*SC & $\begin{array}{l}-11.3 * \\
(-1.70)\end{array}$ & $\begin{array}{l}0.85 \\
(0.25)\end{array}$ & $\begin{array}{l}-8.98 * \\
(-1.77)\end{array}$ & $\begin{array}{l}-0.06 \\
(-0.02)\end{array}$ \\
\hline NORM & $\begin{array}{l}5.00 \\
(1.39)\end{array}$ & $\begin{array}{l}-0.28 \\
(-0.15)\end{array}$ & $\begin{array}{l}3.80 \\
(1.46)\end{array}$ & $\begin{array}{l}0.20 \\
(0.13)\end{array}$ \\
\hline$S C$ & $\begin{array}{l}45.3^{*} \\
(1.72)\end{array}$ & $\begin{array}{l}-3.26 \\
(-0.25)\end{array}$ & $\begin{array}{l}34.1^{*} \\
(1.79)\end{array}$ & $\begin{array}{l}0.31 \\
(0.03)\end{array}$ \\
\hline $\begin{array}{l}\text { Marginal effect } \\
\text { NORM } \\
\text { Marginal effect } \\
\text { SC }\end{array}$ & $\begin{array}{l}-0.25 \\
(-1.27) \\
0.34 \\
(1.23)\end{array}$ & $\begin{array}{l}0.03 \\
(0.38) \\
-0.09 \\
(-0.55)\end{array}$ & & \\
\hline $\begin{array}{l}\text { Log likelihood } \\
\text { Observations }\end{array}$ & $\begin{array}{l}-851 \\
784\end{array}$ & $\begin{array}{l}-2559 \\
2280\end{array}$ & $\begin{array}{l}-930 \\
784\end{array}$ & $\begin{array}{l}-2956 \\
2280\end{array}$ \\
\hline
\end{tabular}

Note: Respondents who considered themselves above or far above average income earners are classified as the high-income group. Respondents who considered themselves below or far below average income earners are classified as the low-income group. Respondents who considered themselves as average earners are included in the estimations of columns (1) and (4) in Table 3(a), but excluded from the sample in Table 3(b). Numbers indicate marginal effect. Values are coefficients in each variable. Sample is limited to people living in the same prefecture they lived in at 15 years of age. In the third line from the bottom, marginal effects of NORM and SC on the probability that $T A X$ is 5 are reported. Numbers in parentheses are z-statistics calculated using robust standard errors clustered in the prefecture. ${ }^{*},{ }^{* *}$, and ${ }^{* * *}$ indicate significance at the $10 \%, 5 \%$, and $1 \%$ levels, respectively. In all estimations, control variables used in Table 3 (b) are included in the model but its results are not reported because of space limitations.

poor. It seems appropriate that the wealthy are likely to perceive the tax as high if their perceptions about tax burdens are determined by self-interest. In this paper, I suggest another possibility: the norm for redistribution leads the wealthy to perceive their tax burden as low even if the individual is not altruistic and acts in their own self-interest. However, to date no empirical research has attempted to examine this possibility. This paper explores how the perceived tax burden is influenced by the degree that neighbors prefer income redistribution. Further, this paper investigates how the influence of neighbors is affected by social capital measured as the degree of neighbors' involvement in community activities; individual-level data and place of residence data were combined to determine this effect. After controlling for individual characteristics, I obtained the following key findings: the norm for redistribution leads rich people to consider the tax burden as low. Further, the effect of the norm increases when there is a greater accumulation of social capital within a residential area. That is, one's perceived burden of tax is influenced by psychological externalities through interactions in the community. Existing research suggests that rich people are more likely to prefer income redistribution in areas where there are higher rates of community participation (Yamamura 2012). However, psychological externalities vary 
according to the type of norms within a community. That is, in the condition that neighbors are unlikely to prefer redistribution, the psychological cost to rich people to oppose redistribution is small. The findings of this paper imply that the norm plays a central role in affecting perceptions regarding tax burdens. The effects of the norm within a community decrease when relationships within the community are weak, even though neighbors prefer redistribution. This is in line with the argument in Baron (2010) that socioeconomic distance influences the degree of enforcement of altruistic moral preferences. This paper used survey data and hence the cost of giving a response is very low. Accordingly, survey responses can be considered as "expressive". According to the expressing voter hypothesis, individuals vote because they are expressing their opinions regarding particular issues, and not because they expect to alter the outcomes of the election (e.g., Tullock, 1971; Copeland and Laband, 2002; Sobel and Wagner, 2004). The results of this paper can be interpreted as suggesting that "pleasing others has a basis in wishing to be liked or popular, which can be achieved by expressively signaling conformity with group-defined norms" (Hillman, 2010, 404). It is difficult to identify the reasons behind the results of this paper. Hence, experimental analysis should be conducted to determine whether the results can be explain by expressive behavior or psychological externalities. In this paper, public spending and the norm proxy are assumed to be exogenous because they are prefecture-level variables rather than individual-level variables. However, there is a possibility of endogeneity bias in these variables, and this is an issue to be addressed in future research. The effect of the residential area characteristics seems to differ according to individual characteristics. That is, even if individuals live in tight-knit communities with high levels of social capital, their preferences are not necessarily influenced their neighbors if they do not socialize in the neighborhood. A lack of data prevents a more detailer exploration of this issue. In addition, Japan is generally characterized as a racially homogenous society. Japan's historical and cultural condition is different from Western countries. The influence of social capital is thought to depend on institutional strength (Ahlerup et al. 2009). Hence, when testing the generality of the findings provided in this paper, it is necessary to examine the hypotheses proposed here using other countries with different historical and cultural background. 


\section{References}

Acemoglu, D., Jackson, M. O. 2014. Social Norms and The Enforcement of Laws. NBER Working Paper No. 20369. doi:10.2139/ssrn.2475920

Alesina, A., Angeletos, G.M. 2005. Fairness and Redistribution. American Economic Review 95, 960-980. doi: 10.1257/0002828054825655

Alesina, A., Giuliano, P. 2009. Preferences for Redistribution. NBER Working Papers 14825. doi: 10.2139/ssrn.1333762

Alesina, A, Glaeser, E, Sacerdote, B. 2001. Why doesn't the United States have a European-style Welfare State? Brookings Papers on Economic Activity 2, 187-277. doi: 10.1353/eca.2001.0014

Alesina, A., La Ferrara, E. 2005. Preferences for Redistribution in the Land of Opportunities. Journal of Public Economics 89, 897-931. doi: 10.1016/j.jpubeco.2004.05.009

Algan, Y., Cahuc, P., Sangnier, M. 2011. Efficient and Inefficient Welfare States, IZA Discussion Paper 5445.』

Alm, J., McClelland, G. H. Schulze, W. D. 1999. Changing the Social Norm of Tax Compliance by Voting. Kyklos 52, 141-171. doi: 10.1111/j.14676435.1999.tb01440.x

Balestrino, A. 2010. Tax Avoidance and the Endogenous Formation of Social Norms, Journal of Socio-economics, 39, 601-609. doi: 10.1016/j.socec.2010.06.003

Baron, D.P. 2010. Morally Motivated Self-regulation. American Economic Review, 100(4), 1299-2329. doi: 10.1257/aer.100.4.1299

Bergh, A., Bjørnskov, C. 2011. Historical Trust Levels Predict the Current Size of the Welfare State. Kyklos 64(1), 1-19. doi: 10.1111/j.14676435.2010.00492.x

Becker, G. 1974. Theory of Social Interaction. Journal of Political Economy, 82, 1063â1093. doi: 10.1086/260265

Becker, G. 1996. Accounting for Tastes, Harvard University Press, London.

Bjørnskov, C. 2006. The Multiple Facets of Social Capital. European Journal of Political Economy 22, 22-40. doi: 10.1016/j.ejpoleco.2005.05.006

Bjørnskov, C., Méon P.G. 2013. Is Trust the Missing Root of Institutions, Education, and Development? Public Choice 157(3), 641-669. doi: 10.1007/s11127-013-0069-7

Chang, W.C. 2010. Religion and Preferences for Redistributive Policies in an East Asian country. Poverty Public Policy 2(4) article 5. doi: 10.2202/1944-2858.1067 
Clark, A., Oswald, A. 1996. Satisfaction and Comparison Income. Journal of Public Economics 61, 359-381. doi: 10.1016/0047-2727(95)01564-7

Copeland, C., Laband, D.N. 2002. Expressiveness and Voting. Public Choice 110, 351â363. doi: 10.1023/A:1013093610591

Corneo, G., Grüner, H.P. 2002. Individual Preferences for Political Distribution. Journal of Public Economics 83, 83-107. doi: 10.1016/S00472727(00)00172-9

Cuccia, A. D., Gregory A. C. 2001. A Closer Look at the Relation between Tax Complexity and Tax Equity Perceptions. Journal of Economic Psychology 22, 113-140. doi: 10.1016/S0167-4870(01)00025-3

Cullis, J., Jones, P., Savoia, A. 2012. Social Norms and Tax Compliance: Framing the Decision to Pay Tax. Journal of Socio-economics 41, 159-168. doi: 10.1016/j.socec.2011.12.003

Derin-Güre, P., Nelsihan, U. 2010. Charitable Giving under Inequality Aversion, Economics Letters 107, 208-210. doi: 10.1016/j.econlet.2010.01.026

Doi, T., Ihori, T. 2009. The Public Sector in Japan. Edward Elgar Publishing, Cheltenham.』

Durlauf, S.N. 2002. On the Empirics of Social Capital. Economic Journal 122, F459âF479 doi: 10.1111/1468-0297.00079

Fehr, E., Schmidt, M. K. 1999. A Theory of Fairness, Competition, and Cooperation. Quarterly Journal of Economics 114(3), 817-868. doi: 10.1162/003355399556151

Feld, L. P., Larsen, C. 2012, Self-perceptions, Government Policies and Tax Compliance in Germany. International Tax Public Finance 19, 78-103. doi: 10.1007/s10797-011-9196-6

Foley, K. 2012. Can Neighbourhoods Change the Decisions of Youth on the Margins of University Participation? Canadian Journal of Economics 45, 167-188. doi: 10.1111/j.1540-5982.2011.01691.x

Fong, C. 2001. Social Preferences, Self-interest, and the Demand for Redistribution. Journal of Public Economics 82, 225-246. doi: 10.1016/S00472727(00)00141-9

Fortin, B., Lacroix, G., Villeval, M-C. 2007. Tax Evasion and Social Interactions, Journal of Public Economics 91, 2089-2306. doi: 10.1016/j.jpubeco.2007.03.005

Galasso, V. 2003. Redistribution and Fairness: A note. European Journal of Political Economy 19, 885-892. doi: 10.1016/S0176-2680(03)00042-9 
Gemmell, N., Oliver M., Abuzer. P. 2004. Tax Perceptions and Preferences over Tax structure in the United Kingdom. Economic Journal 114, F117F138. doi: 10.1111/j.0013-0133.2004.00190.x

Gomez, R., Santor, E. 2001. Membership has its Privileges: the Effect of Social Capital and Neighbourhood Characteristics on the Earnings of Microfinance Borrowers. Canadian Journal of Economics 34, 943-966. doi: 10.1111/0008-4085.00107

Gordon, J.P.F. 1989. Individual Morality and Reputation cost as Deterrents to Tax Evasion. European Economic Review 33, 797-805. doi: 10.1016/00142921(89)90026-3

Greene, W. 2008. Econometric Analysis (sixth ed.), Prentice-Hall, London.

Hammar, H., Jagers C, S., Nordblom, K. 2009. Perceived Tax Evasion and the Importance of Trust. Journal of Socio-economics 38, 238-245. doi: 10.1016/j.socec.2008.07.003

Hayami, Y. 2001. Development Economics: From Poverty to the Wealth of Nations, second ed. Oxford University Press, New York.

Hillman, A.L. 2010. Expressive Behavior in Economics and Politics. European Journal of Political Economy 26, 403-418. doi: 10.1016/j.ejpoleco.2010.06.004

Japan Broadcasting Corporation, 1997. Data Book: Survey on Consciousness of Prefecture Residents (Zenkoku Kenmin Ishiki Chosa, 1996), Japan Broadcasting Corporation Press, Tokyo.

Kadokura, T. 2002. Analysis of Underground Economy concerning Scale of Regional Economy: Time Series Analysis and Comparative Analysis of Prefectures (in Japanese) (Nihon no chikakeizai no kibo ni kansuru jikeiretsu bunseki to todohuken hikaku), (Nihon Keizai Kenkyu), 46, 1-12.

Kerr, W.R. 2014. Income Inequality and Social Preferences for Redistribution and Compensation Differentials. Journal of Monetary Economics 66, 62-78. doi: 10.1016/j.jmoneco.2014.03.002

Klor, E.F., Shayo, M. 2010. Social Identity and Preferences over Redistribution. Journal of Public Economics, 94, 269-278. doi: 10.1016/j.jpubeco.2009.12.003

Lindbeck, A., Nyberg, S., Weibull, J.W. 1999. Social Norms and Economic Incentives in the Welfare State. Quarterly Journal of Economics 114 (1), 135. doi: 10.1162/003355399555936

Luttens, R., Valfort, M.A. 2012. Voting for Redistribution under Desertsensitive Altruism. Scandinavian Journal of Economics 114 (3), 881-907 doi: 10.1111/j.1467-9442.2012.01708.x

Luttmer, P. E. 2001. Group Loyalty and the Taste for Redistribution. Journal of Political Economy 109 (3), 500-528. doi: 10.1086/321019 
Luttmer, P. E. 2005. Neighbors as Negatives: Relative Earnings and Well-being. Quarterly Journal of Economics 120 (3), 963-1002. doi: 10.1093/qje/120.3.963

Luttmer, P. E., Singhal, M. 2011. Culture, Context, and the Taste for Redistribution. American Economic Journal: Economic Policy 3 (1), 157-179. doi: 10.1257/pol.3.1.157

Ohtake, F., Tomioka, J. 2004. Who Supports Redistribution? Japanese Economic Review 55(4), 333-354. doi: 10.1111/j.1468-5876.2004.00318.x

Paldam, M. 2000. Social Capital: one or many? Definition and measurement. Journal of Economic Surveys 14, 629-653. doi: 10.1111/14676419.00127

Pauly, M.V. 1973. Income Redistribution as a Local Public Good. Journal of Public Economics 2 (1), 35-58. doi: 10.1016/0047-2727(73)90009-1

Putnam, R. 2000. Bowling Alone: The Collapse and Revival of American Community, A Touchstone Book, New York.

Rainer, H., Siedler, T. 2008, Subjective Income and Employment Expectations and Preferences for Redistribution. Economics Letters 99, 449-453. doi: 10.1016/j.econlet.2007.09.011

Ravallion, M., Lokshin, M. 2000. Who Wants to Redistribute? The Tunnel Effect in 1990 Russia. Journal of Public Economics 76, 87-104. doi: 10.1016/S0047-2727(99)00064-X

Scholz, J.T., Lubell, M. 1998. Trust and Taxpaying: Resting the Heuristic approach to Collective Action. American Journal of Political Science 42, 398-417. doi: $10.2307 / 2991764$

Scholz, J.T., Pinney, N. 1995. Duty, Fear, and Tax Compliance: the Heuristic Basis of Citizenship Behavior. American Journal of Political Science 39, 490512. doi: $10.2307 / 2111622$

Sobel, J. 2002. Can we Trust Social Capital? Journal of Economic Literature 40, 139-154. doi: 10.1257/jel.40.1.139

Sobel, R.S., Wagner, G.A. 2004, Expressive Voting and Government Redistribution: Testing Tullockâs Charity of the Uncharitable. Public Choice 119, 143-159. doi: 10.1023/B:PUCH.0000024167.07573.ab

Shields, M.A., Wheatley, PS., Wooden, M. 2009. Life Satisfaction and Economic and Social Characteristics of Neighborhoods. Journal of Population Economics 22, 421-443. doi: 10.1007/s00148-007-0146-7

Torgler, B. 2003. Tax Moral, Rule Governed Behavior and Trust, Constitutional Political Economy 14, 119-140. doi: 10.1023/A:1023643622283

Tullock, G. 1971. The Charity of the Uncharitable. Western Economic Journal 9, 379-392. doi: 10.1007/s11166- 012-9139-3 
Tyran, J.-R., Sausgruber, R. 2006. Little Fairness Induce a Lot of Redistribution in Democracy. European Economic Review 50, 469-485. doi: 10.1016/j.euroecorev.2004.09.014

Wenzel, M. 2004. An Analysis of Norm Processes in Tax Compliance, Journal of Economic Psychology 25, 213-228. doi: 10.1016/S01674870(02)00168-X

Wenzel, M. 2005a. Motivation or Rationalization? Causal Relations between Ethics, Norms and Tax Compliance. Journal of Economic Psychology 26, 491-508. doi: 10.1016/j.joep.2004.03.003

Wenzel, M. 2005b. Mis of Social Norms about Tax Compliance: from Theory to Intervention, Journal of Economic Psychology 26, 862-883.

Yamamura, E. 2012. Social capital, Household Income, and Preferences for Income Redistribution. European Journal of Political Economy 28(4), 498511. Social capital, Household Income, and Preferences for Income Redistribution 